Digitalizacja archiwalnych numerów czasopisma naukowego Analecta Cracoviensia 1-24 (1969-1992) i ich publikacja w otwartym dostępie - zadanie finansowane w ramach umowy 672/P-DUN/2017 ze środków Ministra Nauki i Szkolnictwa Wyższego przeznaczonych na działalność upowszechniającą naukę

\title{
GODNOŚĆ SUMIENIA NA PODSTAWIE KONSTYTUCJI II SOBORU WATYKAŃSKIEGO O KOŚCIELE W ŚWIECIE WSPÓECZESNYM
}

Nie podlega obecnie dyskusji fakt, że Sobór Watykański II miał charakter wybitnie duszpasterski, tak ze względu na omawiane zagadnienia, jak i na sposób ich wykładu. Można by wyodrębnić różne wątki nauki Soboru na poparcie tego twierdzenia. Lecz chcę najpierw wskazać na jeden $\mathrm{z}$ nich, mianowicie personalizm, który dzięki nauce Soboru jest przedstawiony $\mathrm{w}$ rozumieniu właściwym, zgodnym $\mathrm{z}$ zasadami nauki Objawienia, co pozwoli łatwiej zrozumieć dalsze wywody.

Sobór stwierdza i uzasadnia godność osoby ludzkiej prawdą o stworzeniu człowieka na obraz i podobieństwo Boże $(\operatorname{Rodz} 1,26)$ i powołaniu go do życia nadprzyrodzonego w Jezusie Chrystusie. W tym właśnie celu wyswobodził nas Chrystus ku wolności (Gal 5, 1) i jako wszczepiony w Chrystusa i powołany do wolności (Gal 5, 13) chrześcijanin staje się wolnym od więzów grzechu (Rzym 6, 1-7). Jest to powołanie i wezwanie kierowane przez Boga do człowieka.

Człowiek winien odpowiedzieć na nie w sposób godny siebie i należyty. Tego rodzaju powołanie nie tylko nie sprzeciwia się godności naturalnej osoby ludzkiej, ale na niej się opiera i daje jej szerokie perspektywy rozwojowe. Jako istota wyposażona $\mathrm{w}$ rozum i wolną wolę, człowiek jest odpowiedzialny za swe postępowanie, które winno nosić znamiona godne dziecka Bożego; jest to ułatwione przez wszechstronne obdarowanie przez Stwórcę, dawcę darów nadprzyrodzonych. Tych kilka zdań jest chyba najkrótszym streszczeniem nauki Soboru na temat osoby ludzkiej i jej relacji do Boga i odwrotnie, ogarniającej całą społeczność ludzi i ich spraw aż do przeznaczeń eschatologicznych włącznie.

Nie miejsce tu na przytaczanie słów Soboru dokumentujących powyższe twierdzenia. Myśli tu zestawione są zawarte w różnych doku- 
mentach soborowych, osnutych na relacji Bóg-człowiek. Nauka ta stanowi nowe ujęcie antropologii chrześcijańskiej i rzutuje mocno na personalistyczne ujmowanie szeregu zagadnien etycznych, zwłaszcza w Konstytucji Gaudium et spes.

Osobę ludzką według tej Konstytucji cechuje jedność substancjalna c i ł ła i duszy ${ }^{1}$, warunkująca ścisłą łączność życia materialnego i nadnaturalnego oraz ścisłą łączność życia moralnego w odniesieniu do wartości doczesnych i wiecznych, a także dynamizm i zdolność do rozwoju osobistego oraz skierowanie do służenia całej społeczności ludzkiej 2.

Są to cechy, które dostatecznie uwypuklają godność osoby ludzkiej. Lecz Sobór uczy, że zdolność świadomego i wolnego pójścia za dobrem i prawdą, czyli wolność jest najgłówniejszym wyznacznikiem wielkości godności osoby ludzkiej ${ }^{3}$.

W każdej z wyliczonych cech kryje się szereg zagadnień, które czekają na badaczy teologów-moralistów, domagając się szczegółowego zbadania i wyjaśnienia. Myślę, że niejedna generacja przeminie, a szereg z nich nadal będzie czekać na opracowanie. Są to bowiem myśli dla teologa nowe, do których dawne ujęcia teol. moralnej nie dały przygotowania $\mathrm{w}$ niejednym przypadku, nawet bez jej własnej winy. Do rozwiązania różnych $\mathrm{z}$ nich brak nam danych, czerpanych z nauk innych, np. teologii biblijnej, socjologii, psychologii, patrologii, itd.

Mamy zamiar zająć się tutaj zagadnieniem godności sumienia, oczywiście w ujęciu Soboru.

Wyliczając cechy osoby ludzkiej, jej godności, według nauki Soboru pominąłem świadomie zagadnienie sumienia, które Sobór wylicza wśród cech świadczących o godności osoby ludzkiej takich np. jak, stworzenie na obraz Boży ${ }^{4}$, natura człowieka ${ }^{5}$. Chcę bowiem zbadać i przedstawić, choć pokrótce, źródło godności sumienia, relację jego do osoby i postulaty, jakie się nasuwają w związku z godnością sumienia ${ }^{6}$.

Ponieważ głównym źródłem jest tekst Konstytucji o Kościele w świecie współczesnym nr 16 - przytaczam go tu w całości.

„(Godność sumienia). W głębi sumienia człowiek odkrywa prawo, którego sam sobie nie nakłada, lecz któremu winien być posłuszny i którego głos wzywający go zawsze tam, gdzie potrzeba, do miłowania i czynienia dobra a unikania zła, rozbrzmiewa w sercu nakazem: czyń to, tamtego unikaj! Człowiek bowiem ma w swym sercu wypisane

1 Por. Konstytucja o Kościele w świecie wspótczesnym, nr 14 (Tekst oficjalny łacińsko-polski znajduje się w: Sobór Watykański II. Konstytucje - Dekrety Deklaracje, Poznań, 1968, ss. 830-987).

2 Por. tamże, $\mathrm{nr}$ nr $15 ; 17 ; 22 ; 24$.

3 Por. tamże, nr 17.

4 Por. tamże, nr 12.

5 Por. tamże, nr nr 14; 15; 17; 22.

6 Por. tamże, nr 16. 
przez Boga prawo, wobec którego posłuszeństwo stanowi o jego godności i według którego będzie sądzony (Rzym 2, 14-16). Sumienie jest najtajniejszym ośrodkiem i sanktuarium człowieka, gdzie przebywa on sam $z$ Bogiem, Którego głos $w$ jego wnętrzu rozbrzmiewa (Por. Pius XII). Przez sumienie dziwnym sposobem staje się wiadome to prawo, które wypełnia się miłowaniem Boga i bliźniego (Mat 22, 37-40; Gal 5, 14). Przez wierność sumieniu chrześcijanie łączą się z resztą ludzi $\mathrm{w}$ poszukiwaniu prawdy i rozwiązywaniu w prawdzie tylu problemów moralnych, które narzucają się tak w życiu jednostek, jak i we współżyciu społecznym. Im bardziej więc bierze górę prawe sumienie, tym więcej osoby i grupy ludzkie cofają się przed ślepą samowolą i starają się dostosować do obiektywnych norm moralności. Często jednak zdarza się, że sumienie błądzi na skutek niepokonalnej niewiedzy, ale nie traci przez to swej godności. Nie można jednak tego powiedzieć w wypadku, gdy człowiek niewiele dba o poszukiwanie prawdy i dobra, a sumienie z nawyku do grzechu powoli ulega niemal zaślepieniu".

Już nawet pobieżne czytanie tekstu pozwala stwierdzić, że Sobór mówi tu o sumieniu każdego człowieka, nie tylko chrześcijanina, oraz że nie widzi potrzeby podawać całej nauki o sumieniu, lecz chce podkreślić jego szczególną godność. Godność sumienia widzi Sobór, jak wynika $z$ tekstu, przede wszystkim $w$ fakcie, że ono odkrywa prawo moralne wypisane w sercu człowieka przez Boga. Daje więc człowiekowi przez to możność zapoznania się z postulatami mądrości i miłości Boga wobec człowieka. Dzięki temu ukazuje mu w sposób dynamiczny, zobowiązujący, drogę, jaką ma kroczyć dziecko Boże do swego Ojca. Człowiek nie jest więc zdany wyłącznie na własne domysły i dociekania, podległe omyłkom i niepowodzeniom, wynikającym z jego zmniejszonej wskutek grzechu zdolności poznawczej. Zdolny jest więc, dzięki sumieniu, bez obawy podjęcia ryzyka omyłki, poznać wolę Boga, wyrażoną $\mathrm{w}$ prawie, co daje mu możność ukazania posłuszeństwa; stanowi ono z jednej strony o jego godności, gdyż czyni wtedy na pewno to, co należy, co jest dobre, a z drugiej strony, daje mu spokój, gdy idzie o moment rozrachunku z Bogiem, spokój dobrego sumienia.

Sumienie czyni to dzięki kontaktowi wewnętrznemu z Bogiem, Którego głos w nim działa i jest słyszalny. Tego rodzaju ujęcie antropomorfistyczne ma wskazać, że kontakt ten ma charakter osobowy. Bóg przecież jest w każdym człowieku, którego ,stworzył z miłości i wciąż z miłości zachowuje" 7, a „człowiek uczestniczy w świetle Bożej myśli" i dzięki temu góruje swym rozumem nad światem „rzeczy" 8. W ten sposób dzięki pomocy Boga człowiek poznaje Jego Samego i przez Niego

8 Por. tamże, nr 15. 
siebie i innych w właściwej relacji i jej wyznaczniki ujęte w przekazywaniu miłości Boga i bliźniego. Poznaje też charakter tej relacji, która przedstawia mu się $\mathrm{w}$ realizowaniu prawa, które staje przed nim w roli niekrępującego go czynnika, lecz wyzwalającego w nim miłość dobra, a co za tym idzie chęć realizowania go, mimo oporów i trudności wewnętrznych czy zewnętrznych; dochodzi w ten sposób do tego, że człowiek szuka Stworzyciela $\mathrm{z}$ własnej ochoty, urzeczywistniając $\mathrm{w}$ sobie prawdziwą wolność, szczególny znak obrazu Bożego w człowieku ${ }^{9}$. Tak pojęte prawo ma za cel danie człowiekowi pełnej doskonałości, według słów św. Pawła: finis praecepti est caritas de corde puro et conscientia bona. (I Tim 1, 5).

Godność sumienia ukazuje się też i w tym, że jest ono zdolne złączyć ludzi w poszukiwaniu prawdy i rozwiązywaniu na jej drodze problemów moralnych tak jednostkowych jak i zbiorowych, społecznych. Warunkiem jednak jest $\mathrm{z}$ jednej strony wierność sumieniu, a $\mathrm{z}$ drugiej jego prawość (c. recta), czyli posłuszeństwo głosowi sumienia urobionego zgodnie z zasadami obiektywnej normy moralnej. Przecież w każdym działa na sumienie ten sam Bóg, Ojciec rodziny ludzkiej. To zapobiega uleganiu samowoli moralnej, wprowadzającej bezład moralny, tak w życiu indywidualnym jak i społecznym. Ten moment działania sumienia jest tak dalece mocny, że działa skutecznie na wszystkich ludzi bez wyjątku, chrześcijan i innych. Działanie to jest możliwe, dzięki pomocy Boga, który wychodzi naprzeciw słabości ludzkiej, gdyż domagając się pełnienia swej woli, w sposób wolny, z świadomego wyboru, czyli osobowo, Sam pomaga do pokonania słabości, dzięki czemu ma prawo domagać się posłuszeństwa.

Godność sumienia, jako odkrywcy prawa i jego herolda nie ulega umniejszeniu nawet, gdy ono się myli i błądzi na skutek niepokonalnej niewiedzy. Ta bowiem wynika $\mathrm{z}$ ułomności ludzkiego bytu, ograniczonego w poznawaniu rzeczywistości w ogóle, a rzeczywistości religijnomoralnej w szczególności, nie zaś ze złej woli; dowodem takiej jest niedbałość w poszukiwaniu prawdy i dobra, co musi doprowadzić do trwania w złu i zaślepienia, czyli stanu, w którym człowiek nie chce znać prawdy, wskutek czego nie dąży do dobra, jakie ona wskazuje i reprezentuje. W takim stanie sumienie zatraca, przynajmniej czasowo, swą godność przewodnika na drodze do Boga. Traci z Nim kontakt, odgradza się od Jego światła i odcina od Jego głosu, w ten sposób zdane samo na swe siły, dzieli z osobą ludzką jej słabość stając się niewolnikiem namiętności. Sw. Paweł (I Tim 4, 2) kwalifikuje ludzi o tego rodzaju sumieniu jako niewolników zła - habentes conscientiam cauteriatam.

9 Por. tamże, nr 17. 
Godność sumienia płynie też i stąd, że jest ono ściśle zespolone z osobą ludzką, której godność Sobór wielokrotnie podkreśla.

Osoba ludzka jest obdarzona wspaniałymi cechami, które są zdolne do rozwoju, w czym, jak widzieliśmy, sumienie ma rolę zasadniczą; ono wraz z nią się bogaci otwierając się coraz bardziej na prawdę Bożą i żyjąc nią dobrowolnie uznaje tę prawdę, a w niej ukazującą się miłość Boga, której się posłusznie powierza, nakłaniając ludzi do jej realizacji. Tym sposobem osoba ludzka dochodzi, lub zdolna jest sama dojść do doskonałości, oraz służyć do udoskonalenia społeczności. Sumienie stwarza podłoże w osobie ludzkiej do odpowiedzialności moralnej za czyn skłaniając do jego wykonania lub wstrzymując je. Dlatego ono właśnie działając w samym centrum osobowości, pod okiem Boga, daje osobie ludzkiej możność decydowania o własnym losie. Nie znaczy to, że sumienie zastępuje decyzję woli lub ją determinuje, lecz że walnie się przyczynia do jej moralnego działania, tzn. dążenia do dobra. Stąd też zgodność działania $\mathrm{z}$ głosem sumienia lub nie, decyduje o tym, że sumienie otrzyma przymiotnik dobre lub złe, co oczywiście przechodzi na podmiot działania, czyli osobę, dzięki czemu człowiek jest dobry lub zły, tak w oczach Boga, jak i ludzi.

Ten ścisły związek godności sumienia z godnością osoby domaga się koniecznego spełnienia szeregu postulatów. Najpierw Sobór stwierdza, że wszyscy ludzie ... mają jako cieszący się godnością osoby nienaruszalne prawo do wychowania... Prawdziwe zaś wychowanie zdąża do kształtowania osoby ludzkiej w kierunku celu jej ostatecznego, a równocześnie do dobra społeczności... Ŝw. Sobór oświadcza też, że dzieci i młodzież mają prawo, aby pobudzano ich do oceny wartości moralnych wedle prawidłowego sumienia...10 Sobór rozciąga zakres wychowania, o ile idzie o chrześcijan na czynniki zawarte w treści prawdy chrześcijańskiej, aby wychowankowie stawali się z każdym dniem coraz bardziej świadomi otrzymanego daru wiary ,...aby się stawali ludźmi doskonałymi na miarę wieku pełności Chrystusowej (Ef. 4, 13)" 11. Tu widzimy nowy element godności osoby. Dotąd Sobór mówił o godności ludzkiej w ogóle, tu do cech godności dodaje element chrześcijański, uświęcenia własnego oraz skuteczniejszego pomagania w chrześcijańskim kształtowaniu świata 12 .

Tak wychowanie, jak i życie odpowiednio do godności osoby ludzkiej domaga się atmosfery wolności, gdyż nawet prawda nie inaczej się narzuca, jak tylko siłą samej prawdy. „Chociaż sam Bóg ukazał ludzkości drogę, na której Jemu służąc ludzie mogą osiągnąć w Chrystusie zba-

10 Por. Deklaracja o wychowaniu chrześcijańskim, $\mathrm{nr} 1$ (Tekst w: Sobór Watykański II, ss. 484-505).

11 Por. tamże, nr 2.

12 Por. tamże. 
wienie ... a wszyscy ludzie są obowiązani szukać prawdy, zwłaszcza w sprawach Boga ... i poznawszy ją, przyjąć i zachowywać, co jest obowiązkiem sumienia, nie działa tu przymus, lecz prawda sama przez siebie" ${ }^{13}$. Dopiero wtedy ich działanie jest zgodne $z$ ich własną naturą, jeżeli w tych sprawach będą korzystać z wolności psychologicznej i wolności od zewnętrznego przymusu. Nakazy Bożego prawa człowiek dostrzega i rozpoznaje za pośrednictwem sumienia swego, do którego jest obowiązany się stosować w całym swym postępowaniu, aby dotrzeć do swego celu - Boga. Nie wolno więc go zmuszać, aby postępował wbrew swemu sumieniu. Ale nie wolno mu też przeszkadzać w postępowaniu zgodnie $\mathrm{z}$ własnym sumieniem ${ }^{14}$. Godność osoby ludzkiej i sumienia jest tak dalece wielka, że nawet Bóg ją szanuje. Od dawna w nauczaniu katolickim panuje zdanie, że człowiek powinien dobrowolnie odpowiedzieć Bogu wiarą; nikogo nie wolno wbrew jego woli do przyjęcia wiary przymuszać (CIC c. 1351), gdyż czlowiek odkupiony przez Zbawiciela i powołany przez J. Chr. ... może siebie oddać objawiającemu się Bogu tylko wtedy, jeśli, pociągany przez Ojca, okazuje rozumne i wolne posłuszeństwo wiary ${ }^{15}$. Bóg wzywa ludzi, aby Mu służyli w duchu i prawdzie; wezwanie takie wiąże ich w sumieniu, ale ich nie zmusza. Zważa On bowiem na godność osoby ludzkiej ${ }^{16}$. Przejawiło się to w bardzo wyrazisty sposób w postępowaniu J. Chrystusa w stosunku do słuchaczy. Dał On świadectwo prawdzie, ale zaprzeczającym nie chciał jej narzucać siłą. Wobec tego godność osoby ludzkiej i sumienia wymaga tym bardziej uszanowania wolności od wszystkich ludzi.

Istnieje jeszcze i trzeci postulat: posłuszeństwo głosowi sumienia. Lecz był on już wymieniony i uzasadniony kilkakrotnie w treści artykułu, dlatego tutaj tylko o nim nadmieniam.

Jeśli Sobór, a w ślad za nim teologowie, mówią przy różnych okazjach o spotkaniu się człowieka z Bogiem, to bez wątpienia zachodzi ono także, a może nawet najczęściej, w sumieniu każdego człowieka, co uwypukla godność osoby ludzkiej i sumienia.

13 Por. Deklaracja o wolności religijnej, nr 1 (Tekst w: Sobór Watykański II, ss. $636-659)$.

14 Por. tamże, nr 3.

15 Por. tamże, nr 10.

16 Por. tamże, nr 11. 


\section{RES UM E}

\section{LA DIGNITÉ DE LA CONSCIENCE À LA LUMIERE DE LA CONSTITUTION PASTORALE SUR L'EGLISE DANS LE MONDE DE CE TEMPS}

Dans sa doctrine, le Concile Vatican II a mis en relief la personne humaine, sa dignité et son rôle

La dignité de la conscience en constitue un élément. Le Concile l'aborde spécialement dans le no 16 de la Constitution pastorale sur l'Eglise dans le monde de ce temps. Les considérations de l'auteur ont pour base son contenu. Elles montrent les sources de la dignité de la conscience, ses relations avec la personne humaine ainsi que quelques postulats à l'adresse de la dignité de la conscience.

Tout d'abord, la dignité de la conscience résulte du fait que grâce à son contact intérieur avec Dieu, elle découvre et révèle, d'une manière dynamique, la loi divine. La conscience doit ensuite sa dignité à la faculté de pouvoir résumer tous les efforts humains dans les recherches de la vérité et pour la solution des problèmes moraux. Enfin, au fond de cette dignité, il y a la participation de la conscience à la dignité de la personne humaine, avec sa misère et sa grandeur, pour laquelle, s'il s'agit de la personnalité morale, elle est un facteur créateur.

De là viennent les postulats: nécessité de la formation propre et de l'éducation de la conscience; devoir de respecter par tous la liberté de la conscience; obéissance à ses indications. 